\title{
Leisure, work and simultaneous study in distance and virtual students Ocio, trabajo y estudio simultáneo de estudiantes en modalidad a distancia y virtual
}

*Leonardo Andrés Aguirre-Cardona, **Isabel Rubio-Florido, *Edwin Alberto Puerto-Rodríguez *Corporación Universitaria Minuto de Dios (Colombia), **Universidad de Deusto (España)

\begin{abstract}
The studies, analysis, reflections and positions regarding the leisure-work relationship is not new and is current, although sometimes it is not tangible and visible at first glance, even more so when the young population in Colombia takes advantage of distance and virtual education to be able to work and generate income and thus pay for a study;Thus, it was sought to analyze the incidence of working and studying simultaneously in the leisure time and spaces of students in distance and virtual mode of the Minuto de Dios-Uniminuto University Corporation in Bogotá-Colombia. Methodologically, the study was executed from a non-experimental, cross-sectional-descriptive design, an on-line questionnaire-type information collection instrument was used with categories: serious leisure, casual leisure, digital leisure and satisfaction with leisure time. A representative sample of 486 students was used with a standard deviation of .5, a confidence level of $98 \%$ and an acceptable sample error limit of .05 for a population size of 12096 students. The incidence of students working and studying simultaneously in distance and virtual modes is reflected in a recurrence that tends to be medium to low in the development of activities of serious leisure, casual leisure and digital leisure; However, satisfaction with leisure time is high, with which it can be inferred that leisure manages to fulfill a restorative function in terms of well-being.
\end{abstract}

Keywords: Leisure time, distance education, work, students, welfare.

Resumen: Los estudios, análisis, reflexiones y posturas frente a la relación ocio-trabajo no es nueva y está vigente, aunque en ocasiones no sea tangible y visible a primera vista, más aún cuando la población joven en Colombia aprovecha la educación a distancia y virtual para poder trabajar y generar ingresos económicos y así solventar un estudio, es así que se buscó analizar la incidencia de trabajo y estudio simultáneo en los tiempos y espacios de ocio de estudiantes en modalidad a distancia y virtual de la Corporación Universitaria Minuto de Dios-Uniminuto en Bogotá-Colombia. Metodológicamente, el estudio fue abordado desde un diseño no experimental, de tipo transversal-descriptivo, se utilizó un instrumento de recolección de información tipo cuestionario on-line a partir de las categorías de ocio serio, ocio casual, ocio digital y satisfacción con los tiempos de ocio. Se trabajó con una muestra representativa de 486 estudiantes teniendo en cuenta una desviación estándar de .5, un nivel de confianza del $98 \%$ y un límite aceptable de error muestral de .05 para un tamaño de población de 12096 estudiantes. La incidencia de trabajo y estudio simultáneo de los estudiantes en modalidad a distancia y virtual, se refleja en una recurrencia que tiende a ser media y baja en el desarrollo de actividades de ocio serio, ocio casual y ocio digital; no obstante, la satisfacción con los tiempos de Ocio, es alta, con lo que se puede inferir que, el ocio logra cumplir una función restaurativa en términos de bienestar.

Palabras claves: Ocio, educación a distancia, trabajo, estudiante, bienestar.

\section{Introduction}

In contemporary educational dynamics, information and communication technologies have facilitated access to training processes in higher education that, until a few years ago, could only be carried out from what is known as face-to-face education. Spatial, temporal and even cultural barriers are being crossed, thus obtaining different possibilities to improve training processes from the technological, economic, communicative and cultu-

Fecha recepción: 10-12-20. Fecha de aceptación: 06-04-21

Leonardo Andrés Aguirre-Cardona

laguirreca1@uniminuto.edu.co ral aspects.

Although the technological impact on education is significant, the realities of people who are dedicated to working and studying simultaneously, taking advantage of virtual tools as the main access route to university education, have generated new ways of understanding, analyzing and to experience leisure times and spaces, impacting on the different areas in which a student operates (Valdemoros-San-Emeterio, M. Á., SanzArazuri, E., \& Ponce-de-León-Elizondo, A., 2017, p. 100).

Thus, the balance between leisure, virtuality, study and work, is permeated by the demands of an 
increasingly demanding society, leading to think that enjoyment of what is done, rest and fun are being configured in aspects of background and therefore requires in-depth study and reflection (Siddiquee, Sixsmith, Lawthom \& Haworth, 2016, p. 37).

Research in relation to leisure articulated with paid work, (Siddiquee, et al, 2016), the past, present and future of leisure studies (Silk, Caudwell \& Gibson, 2017), the reflections made by European teachers with relation to leisure and quality work (Hjalmarsson, 2018), as well as inquiries about digital leisure in contemporary times (Redhead, 2016), provide elements of interest to understand the incidence of work and simultaneous study in the times and spaces of Leisure for students in distance and virtual mode of the Minuto de Dios University Corporation - UNIMINUTO.

Leisure as a field of interest has been studied from different angles, even more so when it takes on special importance in people's lives. For Neulinger (1981), leisure is a subjective state of mind and involves participating in an activity carried out by itself, freely and without coercion. For Iso-Ahola (1980) a theory about leisure must include three fundamental elements: Person (subjective): previous experiences, etc., situation (objective, this is a difference with Neulinger) and time (essential requirement). Csikszentmihalyi (1997) also studies leisure as a subjective experience and sees that defining it only from the dimensions of perceived freedom and intrinsic motivation is limited, in the same way, and in relation to the subject of study of this writing, it does not separate leisure from work either and suggests that its enjoyment can be in any activity and context of life. Following Cuenca (2000), leisure from the humanist perspective cannot be superficial, it must be embedded in human values, in the cultivation of inner life. The discussions, analysis, reflections and positions regarding the work-leisure relationship, is not new and is current, although sometimes it is not tangible and visible at first glance, to this extent, «the way of approaching it and the positions defended were very diverse, but synthesizing the evolution and the process, it can be said that there are three positions that allow us to give a vision of the whole: avoid leisure, earn it and live it « (Cuenca, 2000, p. 261).

The well-being generated through leisure experiences are points of special analysis, since the activities focused on the use of leisure resources lead to generate changes both on the psychological and physical and social levels, leading to structure the idea of therapeutic leisure, which could be said to be characterized by being a resource that through leisure overcomes or improves a problem or situation that negatively affects a person (Rubio, 2012). In this framework, Dumazedier (1964) considered leisure as a significant and necessary factor in society as it contributes to the restoration of the social bond that serves to rest, have fun and develop personality; leisure is presented as compensatory from the rest that the individual recovers from fatigue, fun to escape monotony, and personal development to avoid impersonality.

Ideas about serious leisure and casual leisure are also benchmarks and categories of study. Serious leisure is understood as a «systematic search for an amateur, hobby or voluntary activity that is substantial, interesting and satisfying and where participants find a career in the acquisition and expression of a combination of their special skills, knowledge and experience» (Stebbins, 1992, p. 3). In this regard, studies such as that ofWu, Li, Gao \& Su (2020) show the possibilities of using free time in university educational programs, thus exploring the benefits of serious leisure, from an educational point of view. Stebbins, referenced by Codina, Pestana \& Stebbins (2017), affirms that casual leisure is based on that «immediate, intrinsically rewarding activity; and is a relatively short enjoyable activity that requires little or no special training to enjoy. It is fundamentally hedonic; it is dedicated to the significant level of pure enjoyment or pleasure found there» (p. 68). In this regard, the work advanced by Pooley (2020), analyzed the access to casual leisure activities by exchange university students in South Korea, through mobile devices, thus allowing greater access to activities and in turn generating more ease of cultural and social exchange.

Taking into account that university students in distance and virtual mode are in permanent contact with structures and tools of the digital order, which are increasingly breaking into society and current generations are more frequently surrounded by the internet and technologies that emerge more frequently, and leisure is no stranger to this. Sibilia (2012) expresses that Digital Leisure is an essential part of a culture of entertainment and consumption in general; For their part, Rodríguez \& Ballesteros (2019) state that information technologies related to leisure configure better access to information and optimize the times and spaces available for enjoyment and fun. Digital leisure provides the same benefits as traditional leisure, such as disconnection, escape from the stresses of daily life, improved health, and the construction of a personal 
identity (Bryce, 2001), among others. According to Viñals, Abad \& Aguilar (2014), with digital leisure, new spaces and contexts have been formed that have made possible new opportunities to enjoy free time and transform leisure experiences.

In relation to distance education, it is key to say that this concept has had various thematic approaches, specifically, for this project, distance education is understood «is the teaching-learning process that occurs through the interaction of instructors and students among whom there is a separation of space and / or time» (Flores, Álvarez, Cruz \& Olivera, 2017, p. 31). This idea leads to think that the autonomous learning of the student should be influenced by the different organizations and orientations of the teachers and educational institution in which they carry out their training process, that is, the study carried out by the student, he voluntarily controls his training process, as well as synchronous and asynchronous communication with the teacher. Flores et al. (2017, p. 31), affirms that, to balance the distance between student and teacher, the use of technological and virtual tools is important. Complementary to this approach, it is understood that virtual education is effectively articulated with distance education, in the sense of «facilitating a learning environment based on the use of specific software generically called virtual training platforms, as well as different groups of training environments according to their purpose» (Flores et al., 2017, p. 32).

Complementing the above, studies such as that of Herazo, Núñez-Bravo, Sánchez-Guette, VásquezOsorio, Lozano-Ariza, Torres-Herrera \& ValdelamarVillegas, (2020) in relation to the lifestyles of university students related to the health promotion, give indications against the importance of analyzing leisure in university students who work and study at the same time; In addition, it is essential to contextualize the study of leisure and its social imperative in the context of work (Amaral de Silva, Gonçalves-Junior \& Pazos Couto, 2020, p. 637).

In this order, it is important to state that the incidence of joint work and study is negative for the perception of satisfaction regarding the leisure time of the students consulted. Now, this perception supposes a deficit of leisure that prevents overcoming through it, the needs and dissatisfactions of daily life, in addition to lacking its liberating potential as a source of creativity and identity, necessary for the activities and demands of the university academic life.

\section{Method}

A non-experimental design of a transversaldescriptive type was implemented (HernándezSampieri \& Mendoza, 2018), this allowed to observe and analyze a phenomenon that is the first time that it has been approached in the context of distance and virtual education in the Minuto de Dios University Corporation - Uniminuto, using a questionnaire as an instrument for collecting information and input to analyze the behavior of variables, that were determined from the review and documentary analysis, identification of the study problem and the refinement of the instrument for collecting information in the pilot tests: serious leisure and casual leisure (Stebbins, 2004), digital leisure (Alonso R., referenced by Muriel, D. \& del Valle, RS S, 2018) and satisfaction with leisure in a particular population.

For the design and application of the questionnairetype information collection instrument, the following structuring aspects were taken into account:

First, the review, analysis and adaptation of the escalations elaborated in the studies of Formiga, Ayroza \& Días (2005), Hernández (2001), Martínez-Rodríguez, Iraurgi, Gómez-Marroquín, Carrasco, Ortiz- Marqués \& Stevens (2016), in which the activities that people develop in their leisure time are evaluated, in relation to their degree of satisfaction, development and wellbeing. In the same way, the information provided by the UVD Evaluation Center (2020) of the Minuto de Dios University Corporation - Uniminuto Virtual and Distance Headquarters was used in the years 2019 and 2020, whose data was articulated with the leisure activities of the students in Distance and Virtual mode.

Second, during five months four pilot tests were carried out in order to consolidate the questions for the questionnaire and scale up the instrument. The first exercise consisted of questions addressing basic personal information and an escalation versus leisure activities. The fourth pilot test had a greater adjustment from questions of demographic, academic, work and leisure order. The version of the instrument derived from the analysis of the results of the last test settled on seven questions with two escalations.

Third, the instrument was submitted to the judgment of national and international experts who, based on the preliminary results of the pilot tests, gave approval for its application.

As a result of the pilot tests, the opinion of experts and the statistical reviews, the structured questionnaire 
sought to investigate the following aspects: Sociodemographic information, information on work and study time, having open and closed questions; information on leisure activities (Formiga, et al, 2005; Hernández, 2001) using a Likert scale in relation to the practices of Leisure activities, using the values of $0=$ Never and 5 = always; and information on satisfaction with leisure, where the measurement is given $0=$ Nothing, 1 = Regular, 2 = A lot. (Martínez-Rodríguez, et al., 2016).

The questionnaire was developed through a digital form and was sent to the students through institutional email during the months of May and June of the year 2020; Similarly, approval was obtained from the respective administrative authorities and informed consent was requested from the students to be able to fill out the instrument.

The study population consisted of students who were enrolled at the time of study in any undergraduate program at the Minuto de Dios University Corporation - UNIMINUTO Virtual and Distance Headquarters in the city of Bogotá D.C; of both genders, aged 18 to 60 years.

Considering the total population of 12096 students of the distance and virtual modality of the Minuto de Dios University Corporation - UNIMINUTO, applying the questionnaire to all enrolled students, a total of 486 responses were obtained that, according to the parameters of the formula, to calculate the size of the sample on a finite population, clearing the specific quantities, a confidence level of $98 \%$ is obtained in the application of the instrument, with results higher than expected. (See table 1)

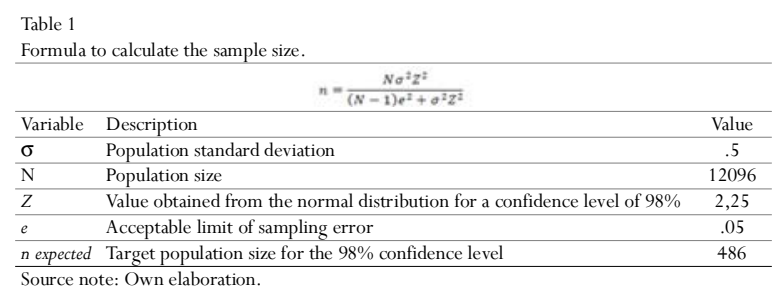

\section{Results}

About a third of the sample was the female population with $71.2 \%$, while the male population was $28.2 \%$. Most of the population lives in urban areas $96 \%$, while only $4 \%$ live in rural areas; the socioeconomic condition places them in the lower-middle social class with $46.4 \%$ located in stratum $3 ; 41.6 \%$ in stratum 2; $7.4 \%$ in stratum 1 and $4.2 \%$ in stratum $4.73 .7 \%$ of the university's student population corresponds to the working social base with full-time working hours; half time $10.5 \%$; and work for hours by $15.8 \%$. The labor field is diverse, although specific trades stand out, some of them related to the careers undertaken; the most representative value is a job that is not in the classification stipulated by the ILO (International Labor Organization) with $21.8 \% ; 14 \%$ to the field of commerce; $13.2 \%$ to financial and professional services; $11.1 \%$ to the field of education and $8.4 \%$ to health services. The ages of the population have an average of 31 years, with a median of 29 and a mode of 28; so that the population is relatively homogeneous in an age group around 30 years.

The results below are classified according to the categories of serious leisure, casual leisure, digital leisure and satisfaction of leisure in terms of time. It was decided to take the quintile model because it bears a proportional relationship with the percentile and decile measures, while dividing the cuts into multiples of 20 percent, allowing a more precise partition and identifying a center that is not identified with a rigid end, allowing a central interpretation when having such cases.

From this, it is evident that serious leisure presents an average of $48.4 \%$, ranking in quintile three $\left(\mathrm{Q}^{3}\right)$; casual leisure $49.3 \%$, ranking in quintile three (Q3); digital leisure $39.4 \%$, ranking in quintile two (Q2); and satisfaction with regard to leisure time presents 62\%, ranking in quintile four (Q4). Hence, serious leisure and casual leisure have a similar recurrence, while digital leisure has the lowest recurrence for activities consulted. It is noteworthy that leisure satisfaction has a significantly positive percentage, implying that for the leisure activities presented, the population is in quintile four (Q4), with a high number of activities in this quintile.

Regarding serious leisure, which includes physical activity and going to shows, theater, etc., it has the highest and lowest average with $60.3 \%$ in quintile four (Q4) and 31.2\% in quintile two (Q2) respectively; while activities such as reading books $57.2 \%$, visiting relatives $57.9 \%$, going to church $48.6 \%$, doing crafts $45.4 \%$, reading newspapers $44.5 \%$, and reading magazines $42.1 \%$, have intermediate averages, ranking in the quintile three (Q3). In general, the Students habitually carry out serious leisure activities, especially physical activity, in relation to studies that have shown a preference for active leisure, particularly sports practice, this being one of the preferred leisure alternatives (Fraguela-Vale, Varela-Garrote \& Varela-Crespo, 2019, p. 419). This activity, along with visiting relatives and reading books, are the most recurrent ones 
representing the three dimensions of the physical, cognitive and social aspects of the human being that imply a performance of integral leisure, with regard to serious leisure. Although the item going to church is part of the items to be evaluated within the scaling proposed by Formiga et al. (2005), it is important to take it into account within the advanced study, since this activity is carried out in leisure spaces and is also part of the cultural roots of the Colombian and Latin American context in general. (See figure 1).

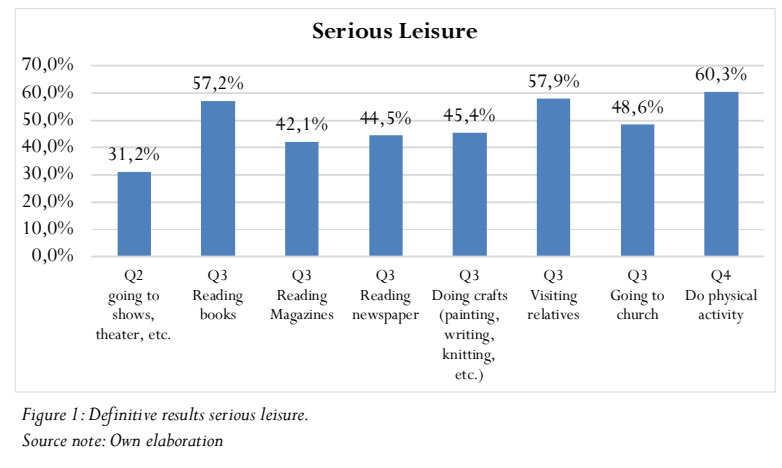

Regarding casual leisure, the activities: listening to music $78.2 \%$ and watching video films $65.6 \%$ are the most recurrent activities, being in quintile four (Q4); while participating in rallies to end environmental, social and political problems 20.9\%; meeting with someone $33.5 \%$ and driving a car or motorcycle $33.7 \%$ are the activities with the least recurrence, ranking in quintile two (Q2). On the other hand, the activities: go to the park $58.1 \%$, watch TV shows $54.7 \%$, present an average level of recurrence. Going to the cinema $51.1 \%$, meeting with friends $50.9 \%$, do activities outside the city $49.6 \%$, going out shopping $49.4 \%$ and going to bars or restaurants $46.1 \%$, placing these activities in quintile 3 (Q3). In this regard, it can be inferred that the most recurrent activities do not imply a displacement and can be considered relaxation; if the results of the category of satisfaction in leisure time are used, a relationship can be established between this aspect and the activity of being calm alone with $65.3 \%$; which shows a coherence between the answers for the category. Meanwhile, regularly recurring activities are typical activities while less recurrent activities are less common with respect to the cultural configuration of the population. The item participate in marches to end environmental, social and political problems is important to take into account in the study, since in the Colombian context, during the time of the review and adjustments of the information collection instrument, the marches of Social protests were frequent throughout the country, where students participated, therefore, the activity was not only referenced by Formiga et al (2005), it is also part of the country's own social dynamics. (See figure 2).

Digital leisure presents virtual social network activities with $64.7 \%$ in quintile 4 (Q4), and online gambling with $17.1 \%$ in quintile $1(\mathrm{Q} 1)$, as those with the highest and lowest recurrence respectively. Meanwhile, online readings $52.5 \%$, online music $51.7 \%$, digital television $47.3 \%$, are activities that are carried out regularly, ranking in quintile $3(\mathrm{Q} 3)$, while online shopping with $38.3 \%$, 3D-4D cinema with 36.3\%, blogs with $33.4 \%$, wikis with $26.3 \%$, and online video games with 25.7\%; has a lower recurrence, being located in quintile $2(\mathrm{Q} 2)$. This category presents a trend below the average in 6 of the 10 activities, and the quartiles where they are located are mostly low Q2 and Q1, which implies that digital leisure activities are not recurrent. The most frequent activities are, in general, more common, while activities that obey a digital culture present low recurrence. It should be noted that the activities that require a more specialized management of technology have a lower recurrence, implying a superficial appropriation of it. On the other hand, the activity of making purchases online and 3D and 4D cinema, have increased their incidence in relation to the pilot tests, being for the first category $26.4 \%$ in the pilot compared to $38.3 \%$ of the final results; and for the second activity $29.5 \%$ in the pilot compared to $36.3 \%$ of the final results; Although the results do not deter-

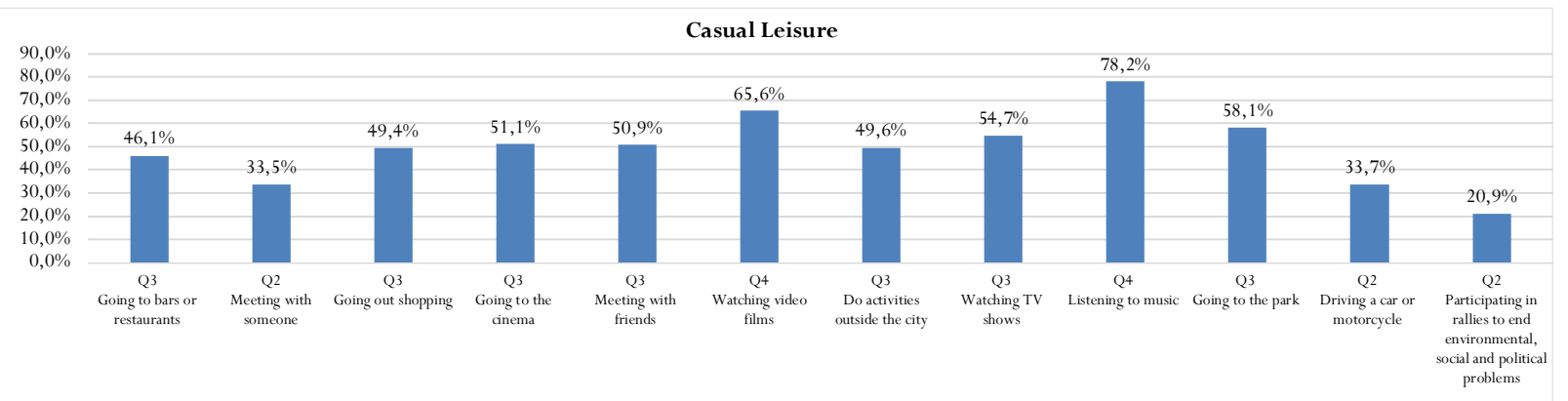


mine a contrast between the results of one survey and the other, it is possible to infer an increasing trend in the use of technology for these specific activities; that can be considered currently in common use, in this sense there are activities that contrast and are diverse in this category. (See figure 3).

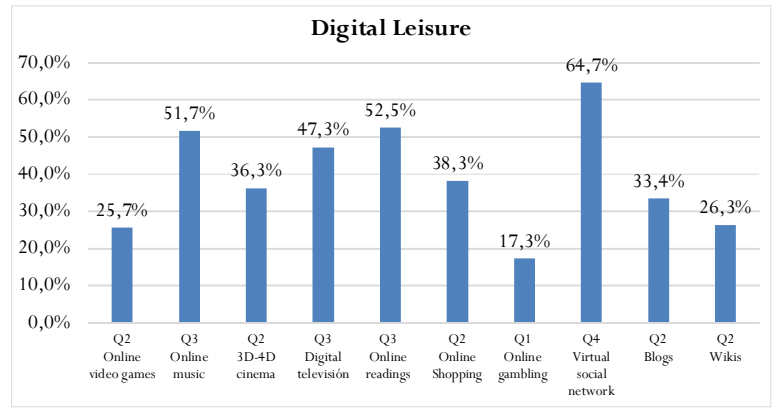

Figure 3: Final results, digital leisure. Source note: Own elaboration

Satisfaction with leisure time has a behavior with a high and homogeneous trend between the different activities, unlike the previous categories in which significant differences are seen between activities. Now, going to mass or meetings in the community presents a lower recurrence to the other activities, being the only one that is in quintile 3 (Q3) with $55.2 \%$. On the other hand, the behavior of the other activities is similar, finding a distance between the highest and the lowest of $.5 \%$, and they are all located in quintile $4(\mathrm{Q} 4)$. Thus, the activities with the highest satisfaction index are being quiet alone with $65.3 \%$ and visiting family or friends with 65.25; closely followed by satisfaction in doing things that are enjoyed $64.2 \%$. A little lower the activities of going out to lunch or dinner or other activities with 61.9\%; and practice hobbies and have fun with other people with the same percentage of $60.7 \%$. In general, this category has a homogeneous behavior with a high index according to quintile 4 (Q4) in which most of the activities are found; it can be said that the population is highly satisfied with the times in the general leisure activities of the questionnaire. (See figure 4).

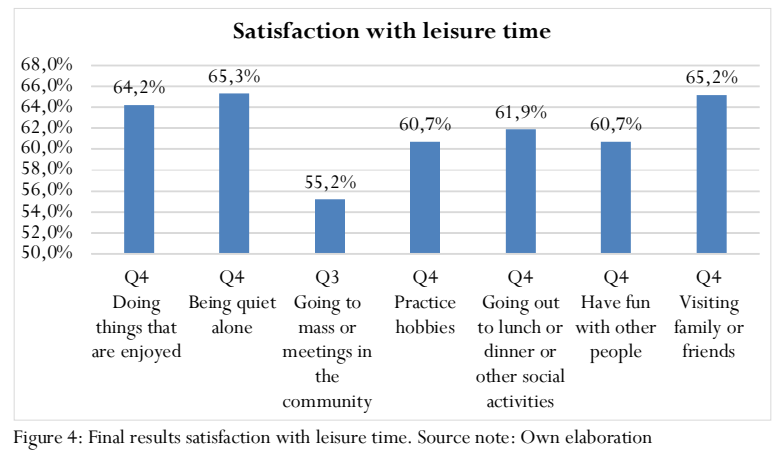

Figure 4: Final results satisfaction with leisure time. Source note: Own elaboration

\section{Discussion}

The routinization of activities, which emerges from an inescapable relationship of work and study, implies understanding the characteristics of a society whose demands are permeated by both subjective and objective values and cultural guidelines, which leads to think that the individual brings out their ability to choose their own ways of generating spaces and times of rest and fun, leisure being a vehicle to achieve well-being transversed by a social reflexivity, therefore, «leisure, in addition to being a manifestation of class conditions, is also a personal distinctive, a reflective expression of identity of the self «(Águila, 2007, p. 111). According to Negre (1993), the leisure-work relationship is mainstreamed by aspects of adult life that reflect a necessary state of productivity that leads to the satisfaction of basic and complex human needs, which depends on an income economic, as a result of carrying out a paid job, which leads to citing what young Colombians increasingly say: if you don't work, you don't study.

It is key to understand that performing a job that generates an economic income generates satisfaction and personal fulfillment, therefore, «it continues to be the most determining axis of the vital structure, of the psychological balance of people and a priority to be able to enjoy quality leisure»(Águila, 2007, p. 168), consequently, it could be thought that work constitutes a channel to generate satisfaction with leisure time, as could be evidenced in the results obtained compared to the satisfaction with leisure time, this is high, reflected in both social and individual activities (see figure 4).

According to the OECD (2020), long working hours and the reduce hours for the enjoyment and use of leisure activities is counterproductive for health, safety is put at risk and stress rates rise. Although when studying and working simultaneously, minimal spaces are generated for leisure activities that result in the wellbeing of students, these spaces can be exploited, that is, leisure in its manifestations framed in the serious and the casual (Stebbins, 2004), is present in the students of the Distance and Virtual modality, which is related to serious leisure activities that are recurrent to a medium degree and, among them, those that refer to physical, cognitive and social aspects, are the most recurrent, implying a medium-high rate in activities that lead to the integrality of the subject. On the other hand, the most frequent casual leisure activities can be considered habitual, while those that are not ordinary have less 
recurrence.

Digital leisure, whose main characteristic is the use of Information and Communication Technologies - ICT and all those tools and devices for digital use for their dissemination, use and enjoyment (Tejero, Balsalobre \& Higueras, 2011), has become an aspect of special interest, that although the results obtained show a medium-low recurrence (see figure 3), those with the highest recurrence are social activities, and those that do not involve specialized management of technology, while activities that do involve this management are less recurrent. Therefore, the increase in the recurrence of activities that are in the process of positioning in digital culture stands out, an increasingly tangible characteristic in the different population segments and even more so, if they are immersed in educational processes in distance and virtual modality.

Satisfaction with leisure time is high among students, although it would be thought that working and studying simultaneously could generate dissatisfaction with leisure, the opposite was observed. From this point of view, one can think that they know how to take advantage of and enjoy the few spaces and times that are not dedicated to work and study, which to a certain extent constitutes the development of activities that relax, generate fun and provide tranquility; which could be translated into a therapeutic leisure. Regarding this topic, García \& Sastre (2019), proposed a program based on leisure activities as a therapeutic alternative for young people who have suffered a first psychotic episode, likewise, Gómez-Mazorra, Sánchez-Oliva \& LabisaPalmeira, (2019) identified that university students who also work, feel greater motivation and intention towards physical activity as a pleasant and enjoyable action, a situation directly related to satisfaction with leisure times. From an active leisure perspective, Zurawik (2020), exposes the positive relationships between a walk as a leisure activity in the natural environment and its psychological and social benefits for well-being. Kim, Kim \& Han (2020), in the same vein of therapeutic leisure, studied the impact of physical activity during leisure times on mental health and the perception of health among people with cancer, which leads us to think that it is valid to project in a lifestyle aimed at active leisure and contribute to the promotion of health, even more so if it is taken as a public policy. (Anjos, \& Silva, 2020, p. 379).

From this perspective, studying and working simultaneously have become a constant social dynamic in the country's young population, from this premise that the resignification of the experience of leisure must be sought from the playful experience, fun, creation, contemplation, with the intention of good living in the academic context (Lemos, Gonçalves-Junior \& Rodríguez-Fernández, 2020, p. 733), and it cannot be ignored that leisure activities in the Colombian and even Latin American sphere, play an important role in the well-being of this population, even more so when the satisfaction is evident with the activities carried out when not working and studying.

\section{Conclusions}

Serious leisure activities are recurrent to a medium degree and, among them, those that refer to physical, cognitive and social aspects, are the most recurrent. Involving a medium-high index in activities that imply the integrality of the subject, while, from the point of view of casual leisure, the experience of activities tends to be more common, typical of the students' daily life. Meanwhile, the activities that do not involve movement and can be considered relaxing have the highest rates, while those that do involve it have average rates.

The activities of a social order facilitated by digital tools have a greater recurrence in the analysis of the digital leisure category, which allows to conclude that the activities that generate rest and fun, which do not imply a high and specialized management of technology, They are more attractive and easily accessible for students who work and study simultaneously, and it is also concluded that those leisure activities that have made their migration from the physical and tangible to the virtual, become easily accessible activities given their versatility and which in turn, given the particularities of the Colombian context, provide a therapeutic space based on fun and relaxation from academic and work activities.

The incidence of working and studying simultaneously of students in Distance andVirtual modalities is reflected in a recurrence that tends to be medium and low in the development of serious leisure, casual leisure and digital leisure activities, however, satisfaction with the leisure time is high, with which it can be inferred that, despite being scarce, they are used and enjoyed to the maximum by the students, perhaps becoming spaces and activities of a therapeutic nature, generating well-being, which in Rubio's words (2012), through leisure, a situation that destabilizes a person can be improved, that is, one would be going to therapeutic leisure that, from the realities of the studied population, can be extrapolated 
to other contexts taking into account the universality of leisure and its possibilities of developing.

\section{Acknowledgment}

The authors express their gratitude to the Minuto de Dios University Corporation-UNIMINUTO, Colombia, for funding the research «Leisure, work and virtuality. the incidence of working and studying simultaneously of the students of the distance and virtual modality of Uniminuto, in their well-being linked to leisure times and spaces», from which this article is the result.

\section{References}

Águila, C. (2007). Sobre el ocio y la posmodernidad. Un análisis sociocrítico. Sevilla:Wanceulen.

Amaral de Silva, R., Gonçalves-Junior, L., \& Pazos Couto, J. M. (2020). Ocio y procesos educativos en el contexto del movimiento de los trabajadores rurales sin tierra (MST) de la región de ribeirão preto -sp - Brasil (Leisure and educational processes in the context of the movement of rural landless workers (MST) in the re. Retos, 38, 637-644. https / / doi.org/10.47197/retos.v38i38.74515

Anjos, V., \& Silva, J. (2020). Política de promoção da saúde no lazer em academias públicas de Campo Grande - MS, Brasil (Health promotion policy in leisure in public gyms in Campo Grande - MS, Brazil) (Política de promoción de la salud del ocio en gimnasios públicos en Campo Grande. Retos, 39, 379 387. https: / / doi.org/10.47197/retos.v0i39.79382

Bryce, J. (2001). The technological Transformation of Leisure. Social Science Computer Review, 19, 7-19.https: / /doi.org/10.1177/089443930101900102

Centro de Evaluación UVD. (2020). Repositorio histórico ingreso y caracterización UNIMINUTO. Documento de trabajo.

Codina, Nuria; Pestana, Jose V. \& Stebbins, Robert A. (2017) «Serious and Casual Leisure Activities in the Construction of Young Adult Identity: A Study Based on Participants' Self-Descriptions». OBETS. Revista de Ciencias Sociales, 12(Extra 1): pp-pp. 65-80. doi: 10.14198/OBETS2017.12.1.12

Csikszentmihalyi, M. (1997). Fluir. Una psicología de la felicidad. Barcelona: Kairos.

Cuenca, M. (2000). Ocio humanista. Documentos de Estudios de Ocio, (16). Bilbao: Universidad de Deusto.

Dumazedier, J. (1964). Hacia una civilización del ocio.
Barcelona: Estela.

Flores Barrios, L., ÁlvarezVelázquez, E., Cruz Luis, E., \& Olivera Gómez, D. (2017). La Educación A Distancia Como Alternativa Para Realizar Estudios De Posgrado En Estudiantes De La Facultad De Contaduría, Tuxpan, De La Universidad Veracruzana. Revista De La Alta Tecnología Y Sociedad, 9(2), 31-37.

Formiga, N. S., Ayroza, I. \& Días, L. (2005). Escala das atividades de hábitos de lazer: construção e validação em jovens. Psic: revista da Vetor Editora, 6(2), 71-79.

Fraguela-Vale, R., Varela-Garrote, L., \& Varela-Crespo, L. (2019). Perfiles de ocio deportivo en jóvenes españoles (15-20 años): un análisis de género (Sports leisure profiles in Spanish youth (15-20 years): a gender analysis). Retos, 37, 419-426. https: / / doi.org/10.47197/retos.v37i37.72055

García, J. V., \& Sastre, P. (2019). Programa de ocio de jóvenes en salud mental. Revista Terapia Ocupacional Galicia, 16(30), 249-264.

Gómez-Mazorra, M., Sánchez-Oliva, D., \& LabisaPalmeira, A. (2019). Actividad física en tiempo libre en estudiantes universitarios Colombianos (Leisure-time physical activity in Colombian university students). Retos, 37, 181-189. https: // doi.org/10.47197/retos.v37i37.71495

Herazo Beltran, Y., Nuñez-Bravo, N., Sánchez-Guette, L., Vásquez-Osorio, F., Lozano-Ariza, A., TorresHerrera, E., \& Valdelamar-Villegas, A. (2020). Estilos de vida relacionados con la salud en estudiantes universitarios (Lifestyles related to health in university students). Retos, 38, 547-551. https: / / doi.org/10.47197/retos.v38i38.72871

Hernández, A. (2001). Cuestionario para la valoración de actividades de ocio y tiempo libre. Anuario de psicología / The UB journal of psychology, 32(3), 67-80.

Hernández-Sampieri, R. H. \& Mendoza, C. (2018). Metodología de la investigación: las rutas cuantitativa, cualitativa y mixta. McGraw Hill México.

Hjalmarsson, M. (2018). Leisure-time teachers' reflections on systematic quality work: approaches and challenges. EarlyChildDevelopment and Care, 1-9.

Iso-Ahola, SE (1980). La psicología social del ocio: investigación pasada, presente y futura. En LA Barnett (Ed.), Investigación sobre el ocio: pasado, presente y futuro (págs. 75 - 93). Champaign, IL: Sagamore

Kim, J., Kim, J., \& Han, A. (2020). The impact of leisure time physical activity on mental health and health 
perception among people with cancer. Health Promotion Perspectives, 10(2), 116. https://doi.org/ 10.34172/hpp.2020.19

Lemos, F., Gonçalves-Junior, L., \& RodríguezFernández, J. E. (2020). Praxis con ociomotricidad: procesos educativos movilizados con estudiantes de pregrado en Educación Física del interior de São Paulo, Brasil (Praxis with idlenessmotricity: educational processes activated with undergraduate students in Physical Education. Retos, 38, 733-738. https: / / doi.org/10.47197/retos.v38i38.73970

Martínez-Rodríguez, S., Iraurgi, I., Gómez-Marroquín, I., Carrasco, M., Ortiz-Marqués N., and Stevens, A.B. (2016). Psychometric properties of the leisure time satisfaction scale in family caregivers. Psicothema, vol. 28 (2), 207-213

Muriel, D., \& del Valle, R. S. S. (Eds.). (2018). Tecnología digital y nuevas formas de ocio (Vol. 60). Universidad de Deusto.

Negre Rigol, P. (1993). El ocio y las edades: estilo de vida y oferta lúdica. Hacer editorial.

Neulinger, J. (1981). The psychology of leisure. Springfield, Illinois: Charles C. Thomas.

OCDE. (2020). Índice para una vida mejor. Recuperado de: http: / / www.oecdbetterlifeindex.org/es/ about/better-life-initiative/

Pooley, A. W. (2020). Accessing leisure in an unfamiliar society via mobile instant messaging: A case study of academic sojourners visiting South Korea. Leisure Studies, 1-17. https://doi.org/10.1080/ 02614367.2020 .1713194

Redhead, S. (2016). Afterword: A new digital leisure studies for theoretical times. LeisureStudies, 35(6), $827-834$. https://doi.org/10.1080/ 02614367.2016 .1231832

Rodríguez, E. y Ballesteros, J.C. (2019). Jóvenes, ocio y TIC. Una mirada a la estructura vital de la juventud desde los referentes del tiempo libre y las tecnologías. Madrid: Centro Reina Sofía sobre Adolescencia y Juventud, Fad. DOI: 10.5281/ zenodo. 3537638

Rubio, I. (2012). El tiempo de ocio de los cuidadores familiares: su relación con la salud y la percepción de carga (Tesis Doctoral). Recuperada de: https:// www.educacion.gob.es/teseo/mostrarSeleccion.do

Sibilia, P. (2012). El hombre postorgánico: cuerpo, subjetividad y tecnologías digitales. Fondo de cultura económica.

Siddiquee, A., Sixsmith, J., Lawthom, R., \& Haworth, J. (2016). Paid work, life-work and leisure: A study of wellbeing in the context of academic lives in higher education. Leisure Studies, 35(1), 36-45. https: / / doi.org/10.1080/02614367.2014.967711 Silk, M., Caudwell, J., \& Gibson, H. (2017). Views on leisure studies: pasts, presents \& future possibilities. https: / / doi.org/10.1080/02614367.2017.1290130

Stebbins, RA (2004b). Entre trabajo y ocio: el terreno común de dos mundos separados. Nuevo Brunswick, NJ: Transacción.

Stebbins, R. A. (1992). Amateurs, professionals and serious leisure. Montreal, QC: McGill-Queen's University Press.

Tejero, C.M.; Balsalobre, C.; Higueras, E. (2011). Active Digital Entertainment (ADE). Social reality, tretas and opportunities of virtual physical activity. Journal of Sport and Health Research. 3(1):7-16.

Valdemoros-San Emeterio, M. A. V., Arazuri, E. S., \& Ponce de León, E. (2017). Ocio digital y ambiente familiar en estudiantes de Postobligatoria. Comunicar: Revista científica iberoamericana de comunicación y educación, (50), 99-108. https: / / doi.org/ 10.3916/C50-2017-09

Veblen,T.B. (1994). Teoría de la clase ociosa. México: Fondo de Cultura Económica.

Viñals, A., Abad, M. y Aguilar, E. (2014). Jóvenes conectados: Una aproximación al ocio digital de los jóvenes españoles. Communication papers-media literacy \& gender studies 3(4), 52-68.

Wu, J., Li, X., Gao, B., \& Su, X. (2020). The Effects of Serious Leisure Involvement on Subjective WellBeing and Successful Aging: A Case Study of YoungOld Participants in Chinese Seniors' Universities. SAGE Open. https://doi.org/10.1177/ 2158244020914559

Zurawik, M. (2020). Moving through spaces-leisure walking and its psychosocial benefits for well-being: a narrative review. Human Movement, 21(2), 1-8. DOI: https: / / doi.org/10.5114/hm.2020.89908

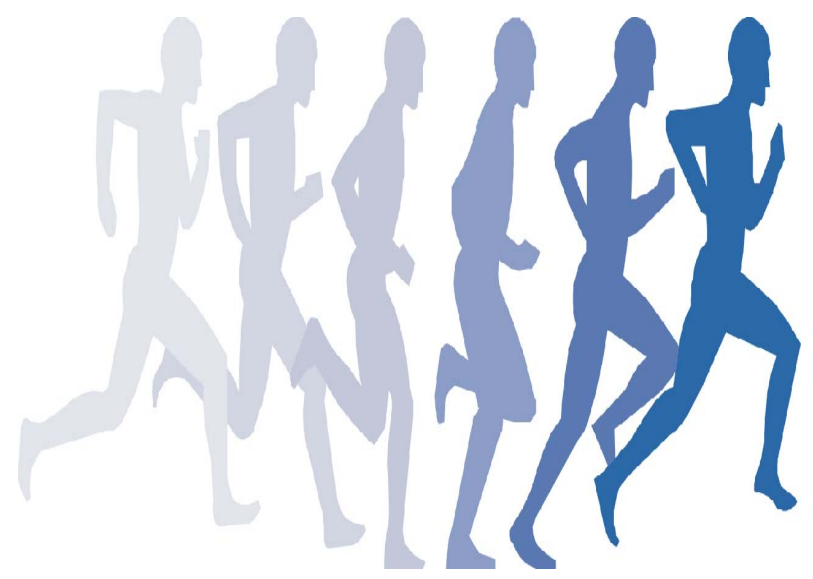

